\title{
Relationship between Taro Leaf Blight (Phytophthora Colocasiae) Disease Resistance and Agronomic Traits of Kenyan and Pacific - Caribbean Taro (Colocasies Esculenta) Accessions
}

\author{
Carren Adhiambo Otieno
}

\begin{abstract}
Taro (Colocasia esculenta) is an important food crop whose production is declining gradually leading to widespread genetic erosion. Despite the limited commercial development, it is important in diet of many in the developing countries. Its corms are baked, roasted, or boiled and the leaves are frequently eaten as vegetable. It is an important source of vitamins, especially folic acid. Phytophthora colocasiae is currently one of the most devastating fungal taro pathogen whose control has relied majorly on use of systemic fungicides which are not environmental friendly. Accessions resistant to taro leaf blight (TLB) can grow without any or fewer fungicide applications. Resistance level of accessions differ largely based on genetic composition, origin and agronomic practices. This fact was the reason for the evaluation of taro accessions from Pacific - Caribbean and Kenya for resistance to TLB under two different trials. Thirteen taro accessions were obtained from previously imported taro from different Pacific - Caribbean and thirteen from six counties in Kenya (Siaya, Kisumu, Busia, Uasin Gishu and Kakamega). They were established in Kakamega, county of Kenya. All the recommended practices were followed for raising a plant except plant protection. CRD was used with three replications. Data collection was started two months of establishment and at one-month interval for five months. Number of suckers and leaves were obtained monthly while corm weight was obtained at harvesting when the plants were seven months old. The disease was scored on a severity scale of 0-9 scale. Resistance was calculated by subtracting the already obtained percent disease severity from $100 \%$.Marked difference in disease resistance was noticed among accessions from different regions and small differences from same region.Disease resistance ranged between $\mathbf{5 8 . 2 7 \%}-\mathbf{8 9 . 7 3 \%}$ for Kenyan and Pacific - Caribbean taro respectively with BL/SM/128 from Samoa portraying the highest resistance of 89.73\%.Correlation between TLB resistance and number of suckers and total leaf area under field study revealed a negative co-efficient.These differences can be used in breeding studies for disease-resistanceand high yield.

Index Terms - Agronomic Traits Resistance, Region, Taro
\end{abstract} leaf blight.

\section{INTRODUCTION}

There is a major constraint for existing breeding programs, particularly with reference to resistance to TLB caused by Phytophthora colocasiae (Lebot et al., 2008).Long term breeding strategy for taro, based on recurrent selection of

Carren Adhiambo Otieno, School of Science, department of biological sciences Rongo University, Rongo, Kenya wide genetic base composed of carefully selected parental genotypes from diverse geographical origin could be used to maximize mutagenic resistance in progenies (Lebot et al., 2008). Controlling plant diseases by use of host resistance and tolerance can make a major contribution towards world food production. It has proven to be an extremely cost-effective and environmentally acceptable approach (Iosefa et al., 2010). The approach involves systematic selection of resistant taro accessions from a population followed by recombination of the selected accessions to form a new population (recurrent selection). The main advantage of this strategy is its ability to accumulate minor resistance genes, which individually would confer minimal resistance (Singh et al., 2010). But together they are likely to be additive and provide durable disease resistance. Several studies have been carried out to determine the resistance level of taro to various diseases and to identify resistant accessions for use in breeding studies. However, there has been difficulty in choosing the right parental genotypes. This has made it difficult to discriminate between susceptible and resistant taro accessions (Quero et al., 2004). More research is required in order to breed for resistance to taro leaf blight disease.

Characteristic defense response in taro like many other host species includes systemic events through signaling and possibly constitutive hydrolytic enzymes, enzyme inhibitors and phytoalexins (Ayogu et al., 2015). However, the phenomenon of resistance, tolerance and susceptibility using epidemiological parameters are incompletely understood.Atak (2016) investigated the resistance level of some grape species to different strains of Uncinula necator, the causal agent of powdery mildew and realized differences in resistance among different grapes (Vitis vinifera) cultivars. Miyasaka et al. (2012) in their study found out that mechanism of resistance found in cultivars resistant to taro leaf blight was effective against other fungal pathogens. Gaforio et al. (2015) realized generally lower resistance of Vitis vinifera cultivars from humid regions of Spain to downy mildew than those from other regions. Results of field evaluations by Tyson and Fullerton, (2015) revealed that, individual taro accessions responded quite differently in successive tests in terms of resistance to taro leaf blight. It was suggested that in some plant-pathogen interactions such as Pythium damping off, downy mildews, Phytophthora diseases and viral infections, the hosts which had attained reasonable maturity and vigour before the outbreak of an infection, would show more resistance to the infection than those in their juvenile stages (Chiejina and Ugwuja, 2013). 
Prajongja et al. (2014) reported that climate of Thailand being very favourable for fungal diseases, even in hybrid grape cultivars some susceptible individuals were discovered. However, during hot, dry conditions, lesions developed slowly, and in some the pathogen died out and the lesions failed to expand further. This suggested a great influence of environmental factors on fungal diseases. The extreme effect of environmental conditions on symptom development makes field assessments of resistance unreliable (Tyson and Fullerton, 2015). In a study by Atak (2016), the resistance levels of some cultivars belonging to different species were determined against two fungal diseases, namely downy and powdery mildew, under climatic conditions in Yalova, South Africa and were found to vary indicating that different cultivars responded differently to taro leaf blight infection. Miyasaka et al. (2012) in his study revealed that most traditional Hawaian taro cultivars did not have high natural resistance to taro leaf blight. Planting heavily susceptible taro could also multiply the number of spores in the field increasing taro leaf blight severity and decreasing the yield of the resistant cultivars (Yalu et al., 2009).

The cultivars with higher disease resistance are intended for use as parents in future breeding programmes because in recent years, the protection of human health and safer food production have emerged as very important issues. Using intensive spray applications to control fungal diseases in grape production is not recommended, especially for fresh consumptions. Singh et al. (2012) reported ineffective management of TLB in the Pacific through chemical and cultural measures and suggested the use of disease resistance cultivars for sustainable management of the disease. Recent breeding programmes in Hawaii have crossed TLB resistant cultivars from other areas of the world with commercial cultivars in Hawaii. According to the 2015-2016 ICAR-CTCRI Annual Report by George, (2016), of the nineteen taro accessions screened artificially, six (IC087153, IC012601, IC012294, IC310104, TCR-267 and TCR-326) showed moderate resistance to taro leaf blight. The knowledge about taro leaf blight resistance is still limited on Kenyan taro accessions. Repeated comparisons with the best cultivar are a useful statistical procedure to identify promising accessions among others for conventional breeding with commercial parents to improve disease resistance and yields.

Miyasaka et al. (2012) in his study revealed that mean dry weight of cultivars were correlated negatively with severity of corm rot and that greater TLB resistance for taro accessions was associated positively with greater dry weight of corm. This meant that taro leaf blight causes corm rot in addition to leaf blight. It was also reported that increasing levels of apparent resistance to TLB and to corm rots in cultivars were associated with increased dry weight corm yields. George (2016) in his ICAR-CTCRI Annual Report 2015-16 revealed that the corm weight of elephant foot taro ranged from 0.2 to $100 \mathrm{~g}$. Preliminary evaluation trial in tannia taro with seven accessions showed that the average cormel yield/plant ranged from $14.40 \mathrm{~g}$ to $85.80 \mathrm{~g}$. Further study byMiyasaka et al. (2012), revealed that low-rainfall periods resulted in poor survival of vegetative propagules and poor corm quality due to loss of starch. Mukherjee et al. (2016) reported that leaf number was highly influenced by environment and dry matter percentage of taro corms were least affected by the environment. The future is uncertain, as it is not clear if alternative food crops can fill the gap left by insufficient production of taro. Maize production has never met the demand and plantains are usually very expensive. Taro leaf blight disease has a potential to create a devastating effect such as reduction in food and household incomes, increased poverty and even starvation (Singh et al., 2012).

The resistance mechanism of taro against TLB is considered to fall under the Horizontal resistance (HR) category based on several host-pathogen interaction models and genetic studies (Robinson, 1996). Ivancic et al. (1994) reported that horizontal resistance was effective against all races of pathogen and has a reputation for durability, therefore referred to as durable resistance. This breeding strategy involves the systematic selection of the resistant individuals from a population followed by recombination of the selected individuals to form a new population (recurrent selection). With HR breeding strategies, it is normal to generate many progenies of good agronomic quality differing widely in their degree of disease resistance. Such a range of material provides the opportunity to match the degree of resistance to the potential risk of disease (Fullerton and Tyson, 2003). On the other hand, Vertical resistance (VR), also referred to as monogenic resistance is generally controlled by one or few major genes and provides complete control against certain races of a pathogen (Singh et al., 2001). It is often characterized by a hypersensitive reaction in the host. Subsequently, new pathogen races evolve that are able to attack previously resistant plants making vertical resistance a non-durable resistance (Singh et al., 2001). According to Atak (2016), hybrid genotypes of $V$. vinifera crossed with $V$. labruscavaried in resistance to fungal diseases and that the most resistant cultivars could be used as resistant donors.A major challenge however, is the reliable identification of the least susceptible individuals in the population for use in the next cycle of inter-crossing. The breeder selects the plants or lines with the lower levels of disease severity and by doing that continuously over the seasons, the level of quantitative resistance will increase fairly rapidly (Do Vale et al., 2001).

Samoa implemented a programme to screen and evaluate the exotic varieties of taro which included; 'Toantal", "Pwetepwet", "Pastora" and "PSB-G2". The first three varieties originated from the Federated States of Micronesia (FSM) whereas "PSB-G2" was obtained from the Philippine Seed Board (Fonoti, 2005). Genetic resistance of cultivars offers the best long-term control of taro leaf blight. However, desirable cultural characteristics and eating qualities are often lost during breeding (Hunter et al, 2001).

Controlling taro leaf blight by use of host resistance and tolerance can make a major contribution towards world food production(Wanyama and Mardell, 2006).However, the phenomenon of incidence, severity, resistance and susceptibility in regard to taro leaf blight disease of taro are incompletely understood particularly in Kenya. This leads to low productivity, low quality planting materials, low level value addition and processing (Wanyama and Mardell, 2006). The relationship between agronomic traits and TLB disease resistance of Kenyan and Pacific-Caribbean taro accessions is unknown and Kenyan taro accessions have rarely been compared with the accessions from Pacific-Caribbean countries so as to determine their level of 
resistance to taro leaf blight. The problem associated with low taro production and low level of TLB resistant accessions in Kenya has not been established. Moreover, the agronomic traits of Kenyan taro have hardly been compared with the accessions from Pacific - Caribbean to enable determination of the highest yielding and TLB disease tolerant taro accessions.Although vast genetic diversity exists in well adapted taro accessions, so far not much systematic study on resistance or susceptibility level of existing taro genetic resources has been conducted in Kenya and the empirical information on resistance to TLB is not available.

Resistant taro accessions had been developed in most Pacific-Caribbean countries. This is why it was important in this present study to compare the Kenyan taro accessions with those screened from Pacific-Caribbean to determine the level of TLB incidence and severity of Kenyan accessions in an effort to breed for resistance to taro leaf blight.Use of fungicides has proved expensive and non-environmentally friendly thus there is need to develop integrated management strategies such as use of resistant varieties which are natural and non-hazardous (Vishnu et al., 2012). The impact of taro leaf blight on Kenyan taro, the continued loss of taro genetic resources is a driving force towards the development of sustainable strategies for the management of the disease. Research on taro leaf blight disease incidence done by Chiejina and Ugwuja (2013), showed that most parts of East Africa produced TLB susceptible taro accessions hence development of genetically resistant accessions alongside other management measures are paramount in solving this present problem.

Host plant resistance is considered the most practical, feasible and economical method of plant disease management. It is necessary to develop an integrated disease management strategy by combining host plant resistance and fungicides as efficient components. The use of resistant taro accessions reduces proliferation of plant pathogens and for this approach to be successful it is essential to analyze the plant pathogen populations for the understanding of the epidemiology, host-pathogen co-evolution, and resistance management (Vishnu et al., 2012). This will help in initiating suitable breeding programmes for the development of resistant cultivars of taro.

\section{MATERIALS AND METHODS}

\section{A. Study Area}

Experiments were established at two locations: Masinde Muliro University of Science and Technology in Kakamega county and Maseno University in Kisumu county. Kakamega town is located within the upper highland agro-ecological zone. Its climate is classified as tropical with a great deal of rainfall even in the driest month. It belongs to group Af (Tropical rainforest) by Koppen- Geiger system of climatic classification (Wambua, 2004). The average temperature is $20.4^{0} \mathrm{C}$. The variation in temperature throughout the year is $2.0^{\circ} \mathrm{C}$. The lowest average temperature usually occurs in July when it is approximately $19.3^{\circ} \mathrm{C}$. The annual rainfall is approximately $1971 \mathrm{~mm}$. Between the driest and the wettest months, the difference in precipitation is $212 \mathrm{~mm}$ (Kakamega -data.org).Kakamega county of Kenya is known to receive high amounts of rainfall throughout the year which is favorable for the fungal pathogen.

MMUST University lies between longitudes of $34^{0} 32^{\prime} 0^{\prime \prime} \mathrm{E}$ $34^{0} 57^{\prime} 0^{\prime \prime} \mathrm{W}$ and latitudes of $0^{0} 07^{\prime} 30^{\prime \prime} \mathrm{N}-0^{0} 10^{\prime} 15^{\prime \prime} \mathrm{S}$ of the equator at an altitude of about $2000 \mathrm{~m}$ above sea level (Wambua, 2004).Maseno University lies within Latitude: $0^{\circ}$ 00' 60.00" N and Longitude: 34 35' 59.99" E and 1503 metres above sea level. Rainfall provided all the water for plant growth except for the first one month that water was provided approximately 2 litres per plant in the morning and evening. Weeding was done twice a month by uprooting and use of a hoe. The soils of Kakamega and Maseno farms showed some similarities being generally loamy sandy, slightly acidic with relatively deep top soil. No chemical was used throughout the study. Harvesting occurred ten months after planting for the first experiment, and for the second and third it was after seven months. A completely randomized design was used in the two fields to avoid biasness because there was no control experiment. This ensured that the extraneous factors affected the treatment conditions equally. The laboratory and greenhouse experiments were conducted at Maseno University due to the availability of materials and equipments. Phytophthora colocasiae isolates were obtained from University of Eldoret laboratory.

\section{B. Preparation of Kenyan and Pacific-Caribbean taro accessions for field evaluation}

Thirteen plants obtained from seven Pacific - Caribbean communities namely Hawai, Papua New Guinea, Samoa, Japan, Indonecia, Malasia and Thailand were used The coding was used to represent the different regions from which they were obtained i.e. BL/HW was from Hawaii, BL/SM from Samoa, BL/PNG from Papua New Guinea, CA/JP from Japan, CE/IND from Indonesia, CE/MAL from Malacia and CE/THA from Thailand. The plants were placed in a greenhouse at MMUST University for two weeks to stabilize before planting. In the greenhouse they were watered every day with approximately 1 liter of water per plant.Kenyan taro accessions (whole plant) were collected from farmer's plots in seven regions in Kenya where taro was frequently grown; Central Kenya in Karole, Kisumu Dungan beach along Lake Victoria, Siaya along Dominion farm, Kakamega-Milimani, Mumias near sugar company, Kitale- Malbasa, Busia, Bundala area, Eldoret, Lange's area. A total of twenty-six taro accessions obtained. They included; KNY/KIS/81, KNY/BSA/41, KNY/ELD/75, BL/HW/8 CE/JP/3, BL/SM/120, KMM/MM1/75, KNY/KIS/20, KNY/CTR/33, $\mathrm{BL} / \mathrm{HW} / 26, \mathrm{BL} / \mathrm{HW} / 80, \mathrm{KMM} / \mathrm{MM} 2 / 76, \mathrm{KNY} / \mathrm{KIS} / 21$, $\mathrm{KNY} / \mathrm{KTL} / 61, \mathrm{CE} / \mathrm{IND} / 1, \quad \mathrm{BL} / \mathrm{SM} / 28, \quad \mathrm{KNY} / \mathrm{SYA} / 50$, $\mathrm{KNY} / \mathrm{KIS} / 22, \mathrm{KNY} / \mathrm{SYA} / 51, \mathrm{CE} / \mathrm{THA} / 7, \quad \mathrm{CE} / \mathrm{IND} / 6$, $\mathrm{BL} / \mathrm{SM} / 48, \quad \mathrm{KNY} / \mathrm{KAK} / 16, \quad \mathrm{CE} / \mathrm{THA} / 24, \mathrm{CE} / \mathrm{MAL} / 14$, BL/SM/111. 
Experimental area measuring $2,240 \mathrm{~m}^{2}(70 \mathrm{~m}$ by $50 \mathrm{~m})$, not previously cultivated was cleared using a machete, hand ploughed and harrowed twice using jembes and hoes before planting. Soil was made into raised beds in preparation for planting. Taro suckers were planted in $60 \mathrm{~cm}$ deep holes and each sucker firmly placed using hands according to the methods of Brooks (2011).The spacing was $0.5 \mathrm{~m}$ between plants and $1.0 \mathrm{~m}$ between rows. Watering was done in the morning and evening for one month approximately one liter per plant using a sprinkler. The plants were arranged in a completely randomized design (CRD) since there were no control experiment in the field The design also ensured that each individual plant had the same chance of becoming a participant in the study.

Total number of suckers infected, total number of leaves infected and the disease incidence were recorded at monthly intervals from the appearance of the first symptom (mainly at 3 months) till the crop was harvested. New partially furled leaves and old leaves touching the ground were not evaluated. Taro leaf blight disease symptoms which include; yellow and red liquid drops in the middle of the lesion with dry solid, brown particles on leaf lamina often with white ring of sporangia around the edge of lesions, which later become papery and may fall out producing 'shot hole' appearance were carefully observed to confirm the disease.

\section{Determination of taro leaf blight disease severity on} Kenyan and Pacific-Caribbean taro accessions under field study

Taro leaf blight disease symptoms which begin with small patches on leaves and water-soaked spots, white mycelium irregular in shape around the lesion (Dipa, 2017) with dark brown color and yellow margins (Vishnu et al., 2012) were carefully observed to confirm the disease. Total area of leaves, total area of leaves infected and the disease severity were recorded monthlyfrom the appearance of the first symptom (at 3 months) till the crop was harvested.

\section{Determination of Leaf area}

Areas of leaves were measured by using non-destructive methods of Chan et al. (1993) and Lu et al. (2002) using the formula $\mathrm{W}_{\mathrm{P}} \mathrm{X} \mathrm{L}_{\mathrm{PA}}$ where

$\mathrm{W}_{\mathrm{P}}=$ Leaf width passing the petiole attaching point

$\mathrm{L}_{\mathrm{PA}}=$ Length of the petiole attaching point to the apex of leaf Areas of leaves infected by the disease were assessed using the maximum length and breadth of the affected leaf area. The measurements were obtained by use of a transparent ruler.

\section{Determination of disease severity}

Disease severity ratings per accession per experiment were undertaken using a subjective score scale of 1-9 adopted from Simongo et al. (2016) (Table 1.1). However, records were made as the percentage leaf area infected.

Table 1: Severity computation

\begin{tabular}{lll}
\hline Scale & \% leaf area infected & Description \\
\hline $0-1$ & 0 & no infection \\
$1-2$ & 3 & $>1 \%$ but $<10 \%$ \\
$2-3$ & 10 & $11-20$ small lesions \\
$3-4$ & 25 & $10 \%$ leaf area infected \\
$4-5$ & 50 & $25 \%$ leaf area infected \\
$5-6$ & 75 & $50 \%$ leaf area infected \\
$6-7$ & 90 & $75 \%$ leaf area infected \\
$7-8$ & 97 & Only few green areas left (much less than 10\%) \\
$8-9$ & 100 & foliage completely destroyed/dead
\end{tabular}

The score was repeated monthly for five months. The start of scoring took into consideration the beginning of disease development i.e. first appearance of TLB symptoms on taro leaves.

D. Determination of the relationship between TLB disease resistance and agronomic traits of Pacific-Caribbeanand Kenyan taro accessions under field study

Healthy leaf area was calculated by subtracting the already obtained percent disease severity from 100 as;Percent healthy leaf area $=100 \%-\%$ disease severity. Where disease severity percentage was calculated per accession per experiment using a subjective score scale of 1-9 adopted from Simongo et al. (2016) to arrive at the disease severity percentages.

Resistance was then calculated using the formula of Fonoti $e t$ al. (2008) as;

Resistance $=$ Percentage healthy leaf area $(100 \%-\%$ disease severity)

\section{Determination of Agronomic traits of Pacific-Caribbean and Kenyan tarounder field study}

The agronomic traits of Kenyan and Pacific taro accessions were determined to identify the most productive taro accession.Morphological and yield trait parameters the accessions were evaluated 2-7 months after planting. This 
was achieved by counting the total number of suckers (corm plants) i.e. the number produced from each plant per month.

Total number of leaves in each plant were counted every month only for fully unfolded leaf according to the methods of Mabhaudhi (2012). The totals from each taro accession were summed up and average determined.Plant height in centimetres was measured using a tape measure at one-month interval across 5 months from the base of the plant immediately above the soil surface up to the base of the second youngest fully unfolded leaf according to the methods of Mabhaudhi, (2012). Corm length was measured in centimeters by use of tape measure from the part attached to the stem to root tip. Corm diameter was also measured in centimetre at the middle and the largest part of the corm by use of Vernier calipers. Corms were cleaned and placed on an electronic weighing scale. They were then measured in grams once at harvesting. The totals from each taro accession were summed up and average determined.

\section{E. Determination of the severity categories and disease reaction of Kenyan and Pacific-Caribbean taro under field study}

The percent disease severity determined in 3.3 above was used to categorize the disease severity index according to Rana (2006). The severity percentage categories were as indicated in Table 2. below.

Table 2. Resistance and susceptibility scale, Rana, (2006)

\begin{tabular}{ll}
\hline Severity percentage range & Disease reaction \\
\hline $0.0-10 \%$ & Resistant (R) \\
$10.1-25.0 \%$ & Moderately resistant (MR) \\
$25.1-50 \%$ & Moderately susceptible (MS) \\
$50 \%$ and above & Susceptible (S) \\
\hline
\end{tabular}

\section{F. Preparation of Kenyan and Pacific-Caribbean accessions for greenhouse evaluation}

\section{Laboratory media preparation}

Preparation of media, sterilization, isolation and maintenance of fungal cultures were done according to the methods of Nath et al. (2014). Petri dishes were placed in sterilization tins and sterilized in hot air oven at $160^{\circ} \mathrm{C}$ for 90 minutes. Potato Dextrose Agar (PDA) media and water used in the study were sterilized at a temperature of $121.6^{\circ} \mathrm{C}$ for 20 minutes in an autoclave as described by Nath et al. (2014). The isolates were then sub-cultured to enhance multiplication. The conditions within the greenhouse were controlled majorly in terms of water availability as two litres of water was provided to each plant every two days. Temperature ranged from $22-27^{0} \mathrm{C}$.

\section{Sterilization and plating of medium}

Work surfaces were sterilized by ethyl alcohol and sodium hypochlorite. Scalpel blades and inoculation loops were sterilized over flame. Plating of medium was done by melting the sterilized medium and distributing in $9 \mathrm{~cm}$ diameter petri plates. This was done aseptically at the rate of $20 \mathrm{ml}$ per plate in the laminar flow-hood chamber and allowed to solidify. Taro leaf blight pathogen isolates previously obtained from University of Eldoret and sub-cultured within Maseno University laboratory onto water agar till pure cultures were obtained were aseptically placed in the middle of each Petri dish using inoculation loops. They were then covered with cover slips. The cultures were incubated for 4 days maintaining them at room temperature in a drawer within the laboratory according to the methods of Shrestha et al. (2012). The remaining isolates were then stored at room temperature in 2ml tubes containing 3-4 plugs of mycelium, 3- and 1-ml water for future use.

\section{Pathogenic nature of isolates}

The pathogenic nature of the isolates was determined by proving Koch's postulates through pathogenicity test according to the methods of Adomako et al. (2016), where disease free taro leaves were placed on sterilized filter paper soaked with distilled water and placed in petri dishes. The plates were inoculated with $2 \mathrm{ml}$ of sporangial suspension containing Phytophthora colocasiae which had earlier been sub-cultured in Maseno laboratory. The leaves were then covered with plastic bags and left for two days at room temperature. After two days, the inoculated sites showed water soaking lesions at the beginning but later turned brown according to the observations of Lin and Ko (2008).

\section{Soil sterilization for greenhouse use}

Black sandy loamy soil from Maseno Botanical garden was sifted to remove stones, plastic materials and plant debris. The soil was steam sterilized in a barrel at $100^{\circ} \mathrm{C}$ for two hours. The sterilized soil was left in the barrel overnight to cool before use according to the methods of Askaru (2010). The taro plants from the previous experiment two of Pacific-Caribbean and Kenyan taro were sampled considering the least and the most susceptible accessions as obtained from the previous result. They included; KNY/SYA/51, $\mathrm{KNY} / \mathrm{KAK} / 16, \quad \mathrm{CA} / \mathrm{JP} / \mathrm{O} 3, \quad \mathrm{CE} / \mathrm{IND} / 01 \quad \mathrm{CE} / \mathrm{THA} / 07$, $\mathrm{KNY} / \mathrm{BSA} / 41, \mathrm{BL} / \mathrm{HW} / 26, \quad \mathrm{BL} / \mathrm{SM} / 80, \quad \mathrm{KNY} / \mathrm{SYA} / 50$, KNY/KTL/61, BL/SM/92. KNY/MU/75, KNY/CNT/33, BL/HW/08, CE/THA/24, KNY/KSM/81. KNY/SYA/50.

Ten-liter plastic buckets filled with the sterilized top soil and the samples placed at $1 \mathrm{~m} \times 1 \mathrm{~m}$ using a complete randomized 
design for the treatments, however, the control experiment was blocked to prevent contamination. The experiment had three replications. The crops were watered with 2 litres per plant in the morning, every two days using clean water and administered at the base of the crop. The tubers were covered with the soil and firmed down according to the methods of Manza et al. (2008).

\section{Inoculum preparation}

Two Phytophthora colocasiae pathogen treatments coded 21R1 and 3R1 isolates were selected for greenhouse inoculation as they had distinctively pure cultures of the pathogen. Distilled water was used on the leaves as control.The inoculation was done by using two most virulent isolates of Phytophthora colocasiae (showing very fast growth) in the culture medium. Mycelia mat from the culture were harvested using sterile scalpel into an electric blender. After blending for five minutes, $200 \mathrm{ml}$ of sterile distilled water was added into $500 \mathrm{ml}$ conical flask and filtered using double layer muslin cloth according to the methods of Manza et al. (2008).

\section{Plant inoculation}

Soil inoculation was done by pouring $20 \mathrm{ml}$ of inoculums suspension at the base of the stem of each plant according to the methods of Manza et al. (2008). This was done three months after planting. Control seedlings were treated with the same quantity of sterile distilled water. Both the inoculated and the control seedlings were covered with polythene bags to increase humidity around the plants according to the methods of Manza et al. (2008). After 24 hours, polythene bags were removed for 20 minutes and the plants watered. Four days after inoculation, the polythene bags were finally removed. There were 16 accession with 3 plants per accession per treatment. There were two pathogen inoculation treatments and one control. The greenhouse experiment data was collected for 5 months. Similar procedure as described on field study for obtaining disease leaf area, agronomic traits, disease severity and disease resistance was used.

\section{G. Data Analysis}

Analysis system (SAS), statistical package 9.1(5), was used to determine the analysis of variance (ANOVA). Correlation analysis was done to establish the relationship between taro leaf blight disease resistance and taro agronomic traits. Whenever there was a significant difference between the means, the least significant difference (LSD) method was used to separate them at $5 \%$ to compare mean differences as described by Obi(2002). Linear model was used to compare variability between regions in terms of disease resistance and agronomic traits. The relationship between taro leaf blight disease resistanceand agronomic traits of taro was determined bygenerating the correlation coefficients and coefficient of determination between disease resistance and agronomic performance according to the methods of Nwanosike et al. (2005).

\section{RESULT}

\section{A. Taro leaf blight disease resistance of Kenyan and Pacific} -Caribbean taro accessions under field study

Table 1.3 below presents disease resistance for both Pacific-Caribbean and Kenyan taro accessions. The accession that had the highest disease resistance of $89.73 \%$ was Samoan $\mathrm{BL} / \mathrm{SM} / 128$ and the lowest resistance was obtained from Kenyan- Siaya accession KNY/SYA/51 with 58.27\%.All the Kenyan taro accessions had disease resistance of below $80 \%$ except accession KNY/KAK/16 from Kakamega county with $82.9 \%$ resistance and KNY/ELD/75 with $84.34 \%$ resistance from Uashin Gishu county. None of the Pacific -Caribbean taro accessions had below $73.81 \%$ resistance and six out of thirteen Pacific-Caribbean accessions had over $80 \%$ resistance. On average, the Pacific-Caribbean highest resistant accession was recorded on Indonesia and Japan with $82.49 \%$ resistance. Malacia, Hawaii, Samoa and Thailand had their average resistance at 82.25, 81.46, 80.44, and 80 . $39 \%$ respectively. The Kenya's least resistant accession was obtained from Busia with a percentage of $64.02 \%$. Siaya, Kisumu, Central Kenya, Mumias had their average disease resistance of $64.16,67.24,67.66$ and $69.46 \%$ respectively. The result revealed generally higher TLB disease resistance with the Pacific-Caribbean taro accessions than the Kenyan taro.

Table 3: Taro leaf blight disease resistance of Pacific -Caribbean and Kenyan taro accessions under Milimani Garden

\begin{tabular}{llr}
\hline Region & Accession & Resistance \\
KENYAN & KMM/MM1/75 & 67.47 \\
KENYAN & KMM/MM2/76 & 71.44 \\
KENYAN & KNY/BSA/41 & 64.02 \\
KENYAN & KNY/CTR/33 & 67.66 \\
KENYAN & KNY/ELD/75 & 84.34 \\
KENYAN & KNY/KAK/16 & 82.9 \\
KENYAN & KNY/KIS/20 & 70.91 \\
\hline
\end{tabular}




\begin{tabular}{llr}
\hline KENYAN & KNY/KIS/21 & 68.57 \\
KENYAN & KNY/KIS/22 & 68.07 \\
KENYAN & KNY/KIS/81 & 61.39 \\
KENYAN & KNY/KTL/61 & 79.16 \\
KENYAN & KNY/SYA/50 & 70.05 \\
KENYAN & KNY/SYA/51 & 58.27 \\
PACIFIC & $\mathrm{BL} / \mathrm{HW} / 08$ & 88.65 \\
PACIFIC & $\mathrm{BL} / \mathrm{HW} / 26$ & 78.13 \\
PACIFIC & $\mathrm{BL} / \mathrm{HW} / 80$ & 77.59 \\
PACIFIC & $\mathrm{BL} / \mathrm{SM} / 111$ & 77.54 \\
PACIFIC & $\mathrm{BL} / \mathrm{SM} / 120$ & 76.91 \\
PACIFIC & $\mathrm{BL} / \mathrm{SM} / 128$ & 89.73 \\
PACIFIC & $\mathrm{BL} / \mathrm{SM} / 80$ & 77.59 \\
PACIFIC & $\mathrm{CA} / \mathrm{JP} / 03$ & 82.49 \\
PACIFIC & $\mathrm{CE} / \mathrm{IND} / 01$ & 75.28 \\
PACIFIC & $\mathrm{CE} / \mathrm{IND} / 06$ & 89.7 \\
PACIFIC & $\mathrm{CE} / \mathrm{MAL} / 14$ & 82.25 \\
PACIFIC & $\mathrm{CE} / \mathrm{THA} / 07$ & 73.81 \\
PACIFIC & $\mathrm{CE} / \mathrm{THA} / 24$ & 86.96 \\
& $\mathrm{Min}$ & $\mathbf{5 8 . 2 7}$ \\
& Max & $\mathbf{8 9 . 7 3}$ \\
\hline
\end{tabular}

\section{B. Agronomic traits (in terms of leaf area) of} Pacific-Caribbean and Kenyan taro under field study in correlation with TLB disease resistance.

There was a statistically significant correlation between resistance and average leaf area as shown in the figure 1 below. When the scattered graph was presented, the line of best fit had a negative slope as shown in figure 1 below. The coefficient was negative indicating that there was less resistance in plants with greater leaf area.

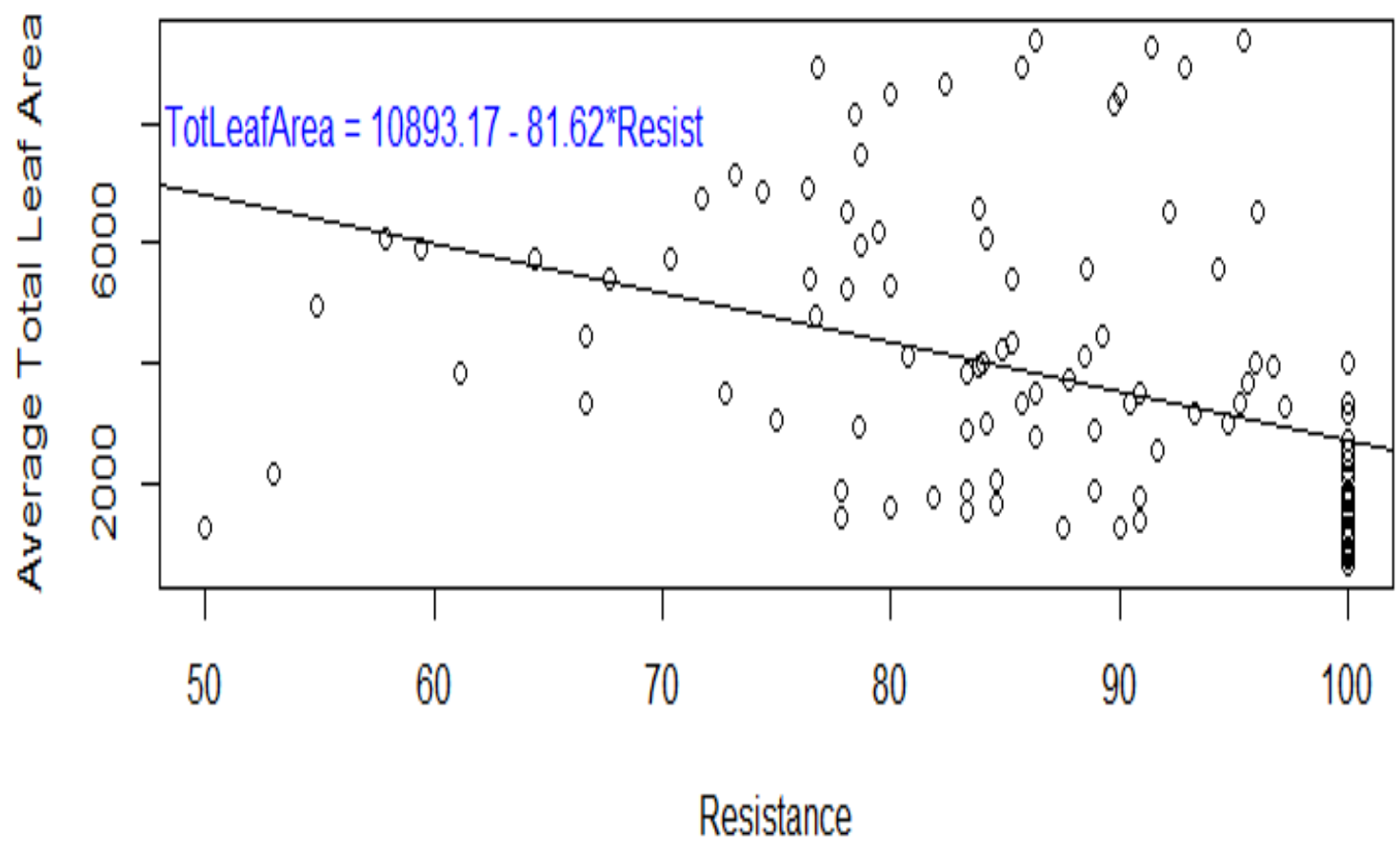

Figure 1: A scatter plot of leaf area versus TLB resistance under Milimani garden 
Relationship between Taro Leaf Blight (Phytophthora Colocasiae) Disease Resistance and Agronomic Traits of Kenyan and Pacific - Caribbean Taro (Colocasies Esculenta) Accessions

C. Agronomic traits (in terms of number of suckers) of Pacific-Caribbean and Kenyan taro under field study in correlation with TLB disease resistance.

The resistance had a statistically significant correlations with total number of suckers. The correlation was however negative with a coefficient 0.1106 in thatincrease in the number of suckers led to a decrease in disease resistance as shown in figure 2 below

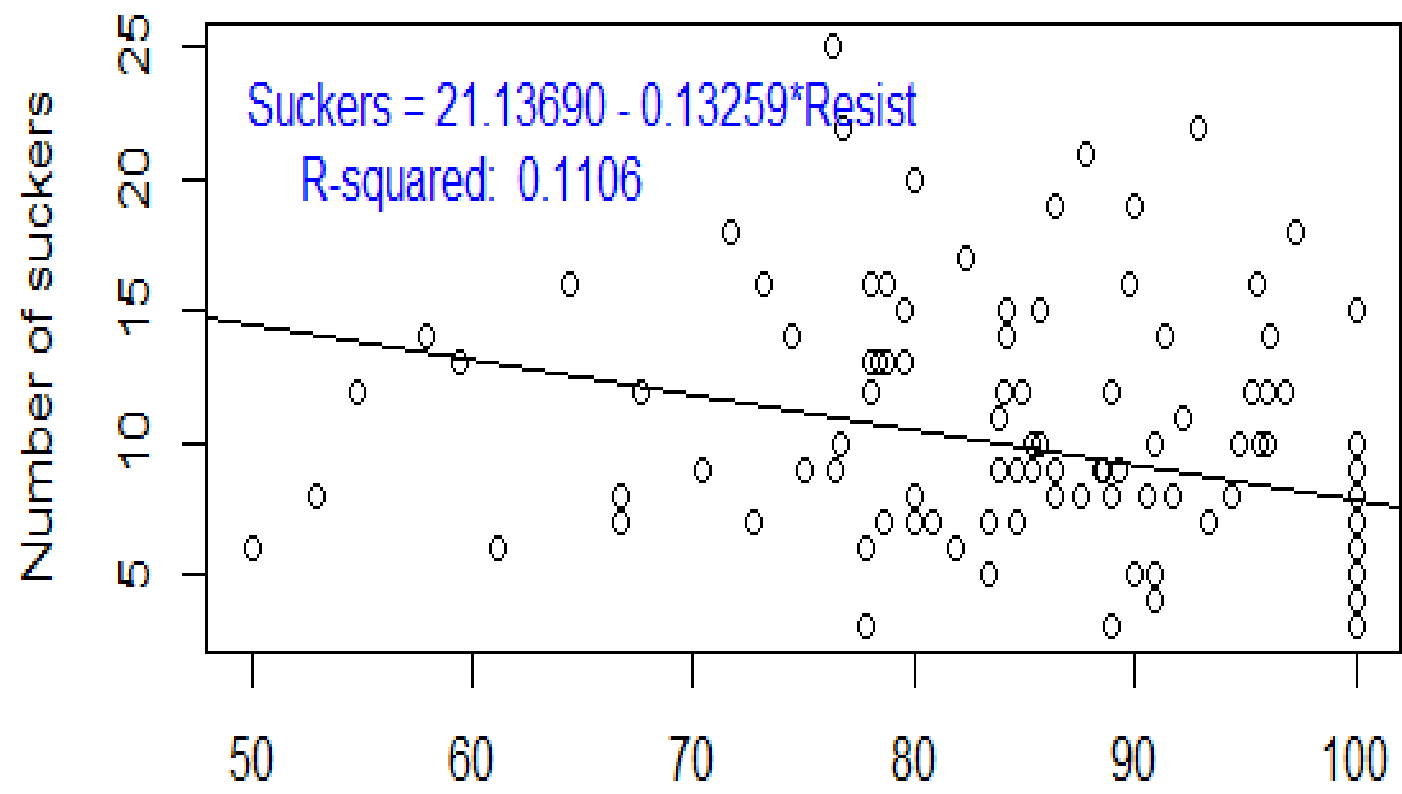

\section{Resistance}

Figure 2:A scatter plot of the number of suckers in a month versus the resistance in the Second experiment that all the accessions except one (CE/THA/07) were

D. Level of resistance of Pacific-Caribbean taro accession against TLB disease under field study moderately resistant. None of the accessions was resistant and none was susceptible (Table 4).

The result on field study were as outlined on table 4 The pooled average disease resistance of the accessions revealed

Table 4 :Level of resistance of Pacific-Caribbean taro accession against TLB disease under field study

\begin{tabular}{|c|c|c|c|}
\hline \multirow[b]{2}{*}{ Scale } & & & \multirow[t]{2}{*}{ Accession identity } \\
\hline & Level of resistance & No of accessions & \\
\hline $0-1$ & $\mathrm{R}$ & None & None \\
\hline & & & $\begin{array}{l}\mathrm{BL} / \mathrm{SM} / 26, \mathrm{BL} / \mathrm{HW} / 08, \mathrm{BL} / \mathrm{HW} / 80, \mathrm{BL} / \mathrm{SM} / 111, \\
\mathrm{BL} / \mathrm{SM} / 120, \mathrm{BL} / \mathrm{SM} / 28, \mathrm{BL} / \mathrm{SM} / 48, \mathrm{CE} / \mathrm{IND} / 01\end{array}$ \\
\hline $1-2$ & MR & 12 & CE/IND/06, CE/JP/03, CE/MAL/14, CE/THA/24 \\
\hline $2-3$ & MS & 1 & CE/THA/07 \\
\hline $3-4$ & $\mathrm{~S}$ & None & None \\
\hline
\end{tabular}

*Host responses: $\mathrm{R}=$ Resistant; MR = Moderately resistant; MS = Moderately susceptible; $\mathrm{S}=$ Susceptible.

4.20 below. Ten of the accessions were moderately resistant,

E. Level of resistance of Kenyan taro accession against TLB two, moderately susceptible and only one (KNY/ELD/75) was resistant. None of them was susceptible to taro leaf disease under field study

The result on Kenyan taro accession varietal disease blight.

resistance under field study two was as illustrated on table 
Table 5: Level of resistance of Kenyan taro accession against TLB disease under Milimani garden

\begin{tabular}{llll}
\hline Scale & $\begin{array}{l}\text { Level of } \\
\text { resistance }\end{array}$ & $\begin{array}{l}\text { No of } \\
\text { accessions }\end{array}$ & Accession identity \\
\hline $0-1$ & $\mathrm{R}$ & 1 & $\mathrm{KNY} / \mathrm{ELD} / 75$ \\
$1-2$ & $\mathrm{MR}$ & 10 & $\mathrm{KMM} / \mathrm{MM} 1 / 75, \mathrm{KMM} / \mathrm{MM} 2 / 76, \mathrm{KNY} / \mathrm{CTR} / 33, \mathrm{KNY} / \mathrm{KAK} / 16$, \\
& & & $\mathrm{KNY} / \mathrm{KIS} / 20, \mathrm{KNY} / \mathrm{KIS} / 21, \mathrm{KNY} / \mathrm{KIS} / 22, \mathrm{KNY} / \mathrm{KIS} / 81, \mathrm{KNY} / \mathrm{KTL} /$ \\
& & & $61, \mathrm{KNY} / \mathrm{SYA} / 50$ \\
$2-3$ & $\mathrm{MS}$ & 2 & $\mathrm{KNY} / \mathrm{BSA} / 41, \mathrm{KNY} / \mathrm{SYA} / 51$ \\
$3-4$ & $\mathrm{~S}$ & None & None \\
\hline
\end{tabular}

Host responses: R = Resistant; MR = Moderately resistant; MS = Moderately susceptible; $\mathrm{S}=$ Susceptible

from Kenyan accession from Busia county KNY/BSA/41. Of

F. Relationship between TLB disease resistance and agronomic traits of Pacific-Caribbean and Kenyan taro accessions under greenhouse study

The greenhouse experiment result on TLB disease resistance is presented on table 4.21 below. The highest disease resistance of $89.69 \%$ was obtained from Hawaii accession $\mathrm{BL} / \mathrm{HW} / 26$ and the lowest resistance of $55.06 \%$ was recorded the eight Pacific-Caribbean accessions examined, three had over $83.32 \%$ resistance. None of the Kenyan accessions observed recorded more than $73.47 \%$ resistance. The average TLB disease resistance for Pacific-Caribbean taro accessions was $78.59 \%$ and for Kenya was $67.95 \%$. The result revealed low disease resistance on Kenyan taro than the Pacific -Caribbean.

Table 6: Taro leaf blight disease resistance of Pacific -Caribbean and Kenyan taro accessions under greenhouse experiment

\begin{tabular}{llr}
\hline Region & Accession & Resistance \\
\hline KENYAN & KNY/BSA/41 & 55.06 \\
KENYAN & KNY/CNT/33 & 63.95 \\
KENYAN & KNY/KAK/16 & 78.14 \\
KENYAN & KNY/KSM/81 & 66.44 \\
KENYAN & KNY/KTL/61 & 67.34 \\
KENYAN & KNY/MU/75 & 73.47 \\
KENYAN & KNY/SYA/50 & 72.74 \\
KENYAN & KNY/SYA/51 & 66.42 \\
PACIFIC & BL/HW/08 & 78.73 \\
PACIFIC & BL/HW/26 & 89.68 \\
PACIFIC & BL/SM/80 & 74.38 \\
PACIFIC & BL/SM/92 & 85.53 \\
PACIFIC & CA/JP/03 & 83.32 \\
PACIFIC & CE/IND/01 & 75.32 \\
PACIFIC & CE/THA/07 & 73.54 \\
PACIFIC & CE/THA/24 & 68.28 \\
& Min & $\mathbf{5 5 . 0 6}$ \\
& Max & $\mathbf{8 9 . 6 8}$ \\
\hline
\end{tabular}

Summary of the level of resistance to taro leaf blight of Pacific-Caribbean and Kenyan taro is shown on figure 3 and 4 below. Difference in disease resistance among the two categories of accessions inoculated in this study indicated that there was difference in varietal reaction to TLB pathogen and also aggressiveness of the pathogens used for inoculation. 
Relationship between Taro Leaf Blight (Phytophthora Colocasiae) Disease Resistance and Agronomic Traits of Kenyan and Pacific - Caribbean Taro (Colocasies Esculenta) Accessions

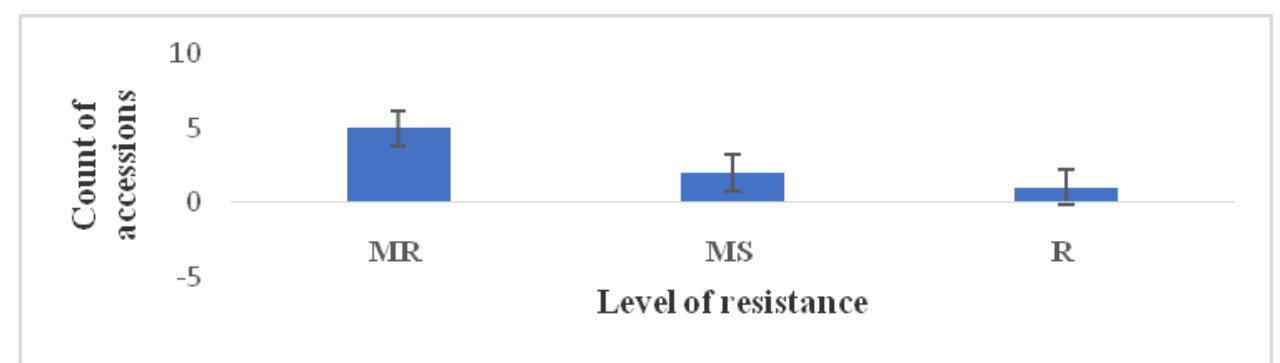

Host responses: $\mathrm{R}=$ Resistant; $\mathrm{MR}=$ moderately resistant; $\mathrm{MS}=$ moderately susceptible; $\mathrm{S}=$ Susceptible.

Figure 3: Count of Pacific- Caribbean taro accessions by level of resistance to taro leaf blight under greenhouse experiment of September 2015 to January 2016

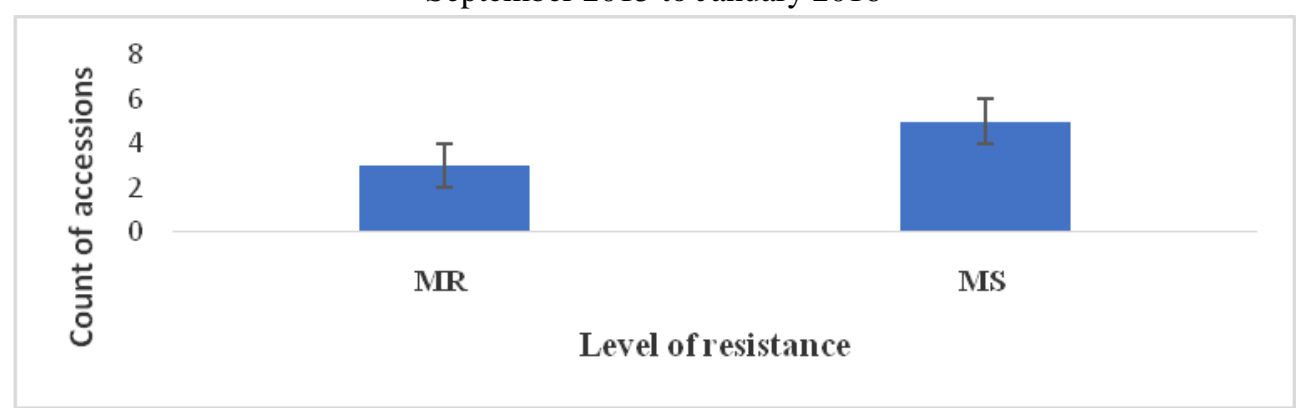

Host responses: $\mathrm{R}=$ Resistant; $\mathrm{MR}=$ Moderately resistant; $\mathrm{MS}=$ Moderately susceptible; $\mathrm{S}=$ Susceptible.

Figure 4: Count of Kenyan taro accessions by level of resistance to taro leaf blight under greenhouse experiment of September 2015 to January 2016

\section{G. Level of resistance of Pacific-Caribbean taro accession} against TLB disease under greenhouse study

The result on greenhouse experiment is shown on table 6. Compared to the experiment one of April-November 2013, more Pacific-Caribbean accessions became susceptible or moderately susceptible to taro leaf blight as shown on table 6 . The disease reaction of the eight accessions of taro showed differences in resistance to isolates of Phytophthora colocasiae. In the pooled response of taro to TLB disease, accession BL/HW/26 emerged resistant while $\mathrm{CE} / \mathrm{THA} / 24$ and BL/SM/80 were moderately susceptible (Table 6). This variation could indicate that there existed differences in resistance levels and degree of response of various taro accessions to inoculated blight pathogen. This is because the genetic makeup of taro may promote the growth and spread of the pathogen or resist and eliminate it altogether. Cadle-Davidson et al. (2011) investigated the resistance level of some Vitis species to different strains of Uncinula necator, the causal agent of powdery mildew. They determined resistance level differences amongst accessions similar to this current study. Furthermore, the findings of Atak (2016) was consistent with this study that resistance levels in cultivars can differ for different isolates. The finding further stated that while species were important in resistance breeding, the resistance level of each accession should be determined.

Table 7:Level of resistance of Pacific-Caribbean taro accession against TLB disease under greenhouse study

\begin{tabular}{clcl}
\hline Scale & $\begin{array}{c}\text { Level of } \\
\text { resistance }\end{array}$ & $\begin{array}{c}\text { Number of } \\
\text { accessions }\end{array}$ & Accession identity \\
\hline $0-1$ & $\mathrm{R}$ & 1 & $\mathrm{BL} / \mathrm{HW} / 26$ \\
& & 5 & $\mathrm{BL} / \mathrm{HW} / 08, \mathrm{BL} / \mathrm{SM} / 92, \mathrm{CA} / \mathrm{JP} / 03, \mathrm{CE} / \mathrm{IND} / 01$, \\
$1-2$ & $\mathrm{MR}$ & $5 \mathrm{CE} / 07$ \\
$2-3$ & $\mathrm{MS}$ & 2 & $\mathrm{CE} / \mathrm{THA} / 24, \mathrm{BL} / \mathrm{SM} / 80$ \\
$3-4$ & $\mathrm{~S}$ & $\mathrm{NONE}$ &
\end{tabular}

Host responses: R = Resistant; MR = Moderately resistant; MS = Moderately susceptible; $\mathrm{S}=$ Susceptible observed.It was evident that none of the Kenyan accessions

H. Resistance of Kenyan taro accession against TLB disease under greenhouse study

Table 4.26 below illustrates the summary of Kenyan taro accession disease resistance under greenhouse study. For the Kenyan taro accessions, moderate susceptibility was evaluated in the greenhouse was resistant to taro leaf blight and that accessions belonging to the same species differed in their resistance to pathogens. Similar to the findings in this study, Atak (2016) reported that $V$. vinifera cultivars generally had low disease resistance, but it was also reported that resistance level of cultivars varied. It agreed with 
Shakywar et al. (2013) who evaluated ninety taro accessions in India and observed that none was resistant to taro leaf blight. In the pooled taro disease reaction, KNY/KAK/16, KNY/MU/75 and KNY/SYA/50 were moderately resistant. Mishra (2010) supported this finding in his report that Phytophthora colocasiae pathogen usually produce an elicitor which is recognized by its host taro, so that once it is detected the taro plant can limit the spread of pathogens through a hypersensitive response that induces apoptosis. This makes the unaffected tissue to develop a systemic acquired resistance which renders the entire plant more resistant to pathogen attacks (Lam et al., 2001).

Table 8:Level of resistance of Kenyan taro accession against TLB disease under greenhouse experiment

\begin{tabular}{clcc}
\hline Scale & $\begin{array}{c}\text { Level of } \\
\text { resistance }\end{array}$ & $\begin{array}{c}\text { Number of } \\
\text { accessions }\end{array}$ & Accession identity \\
\hline $0-1$ & $\mathrm{R}$ & $\mathrm{NONE}$ & \\
$1-2$ & $\mathrm{MR}$ & 3 & $\mathrm{KNY} / \mathrm{KAK} / 16, \mathrm{KNY} / \mathrm{MU} / 75, \mathrm{KNY} / \mathrm{SYA} / 50$ \\
& & & $\mathrm{KNY} / \mathrm{BSA} / 14, \mathrm{KNY} / \mathrm{CNT} / 33, \mathrm{KNY} / \mathrm{KIS} / 81$, \\
$2-3$ & MS & 5 & $\mathrm{KNY} / \mathrm{KTL} / 61, \mathrm{KNY} / \mathrm{SYA} / 51$ \\
$3-4$ & $\mathrm{~S}$ & $\mathrm{NONE}$ &
\end{tabular}

Host responses: R = Resistant; MR = Moderately resistant; MS = Moderately susceptible; $\mathrm{S}=$ Susceptible

I. Progress of taro leaf blight disease infestation on tolerant Pacific-Caribbean accession CE/IND/06 and susceptible Busia accession KNY/BSA/41 leaves

Plates 4.1 to 4.4 below showed the progress of taro leaf blight on a Pacific - Caribbean accession CE/IND/16 known to be moderately tolerant to taro leaf blight. Plate 1 showed a healthy leaf, 2 showed lesion spots developing on leaves, 3 indicated enlarged lesion surrounded by yellowish discoloration on leaf while 4 , the dark brown halo was then concentrated at the apex. The disease progress was slow and localized, an indication of resistant accessions. The finding was in concurrence withthe following symptoms used to determine resistant variety by Jugurnauth et al. (2001); no leaf showing symptoms of taro leaf blight, mild symptoms on one or less than half of the leaves and ability to hold in the field after it is ready for harvesting without rotting. Wilson (1990) finding was consistent with this finding that in a resistant plant, a diseased tissue falls away from spots (short holes symptoms).

Stages of development of symptoms of TLB disease of taro on a moderately resistant taro

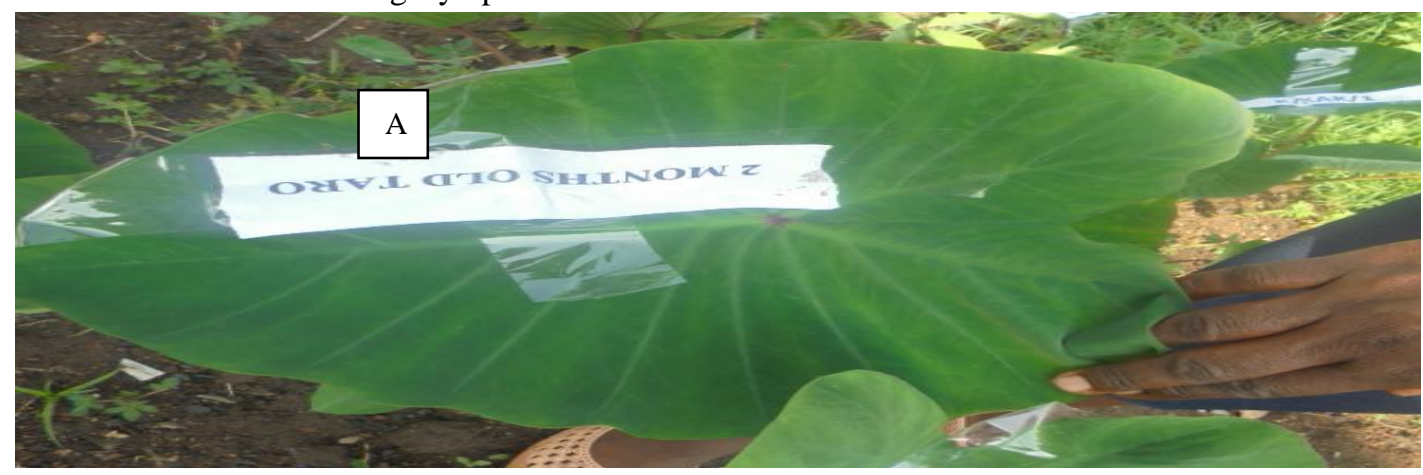

Plate 1: Healthy tolerant leaf

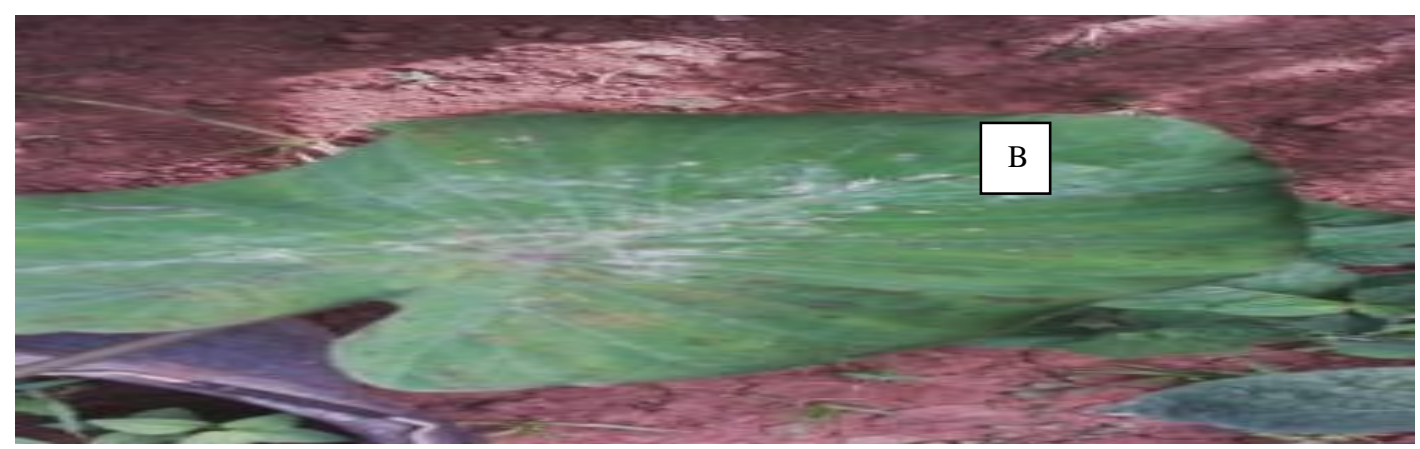

Plate 2: lesion spots on lamina 
Relationship between Taro Leaf Blight (Phytophthora Colocasiae) Disease Resistance and Agronomic Traits of Kenyan and Pacific - Caribbean Taro (Colocasies Esculenta) Accessions

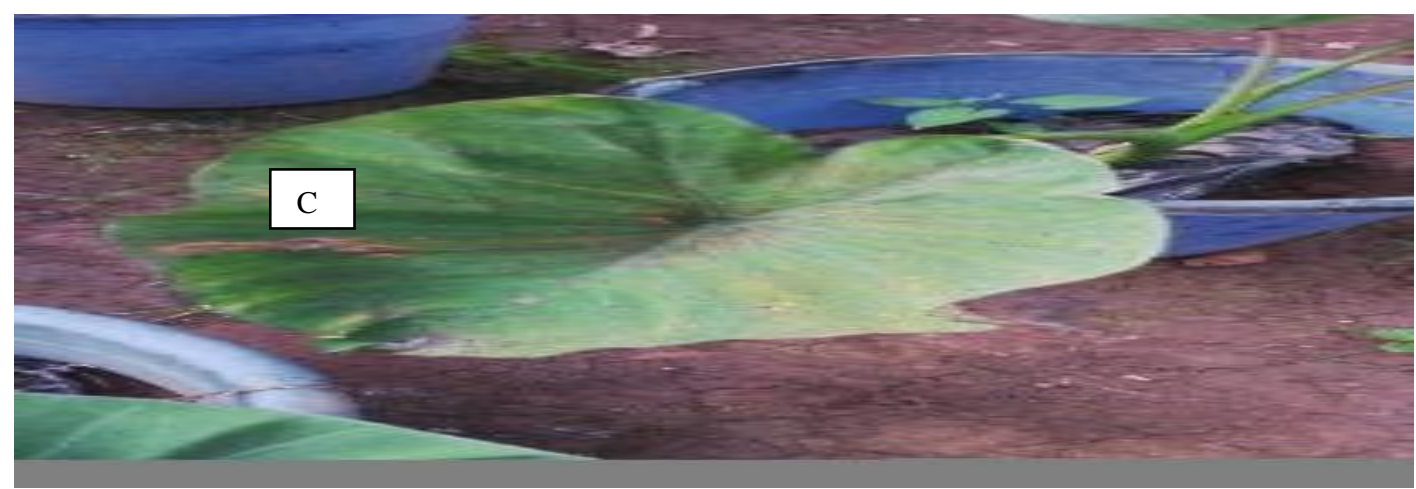

Plate 3:lesion spots surrounded by yellow halo on lamina

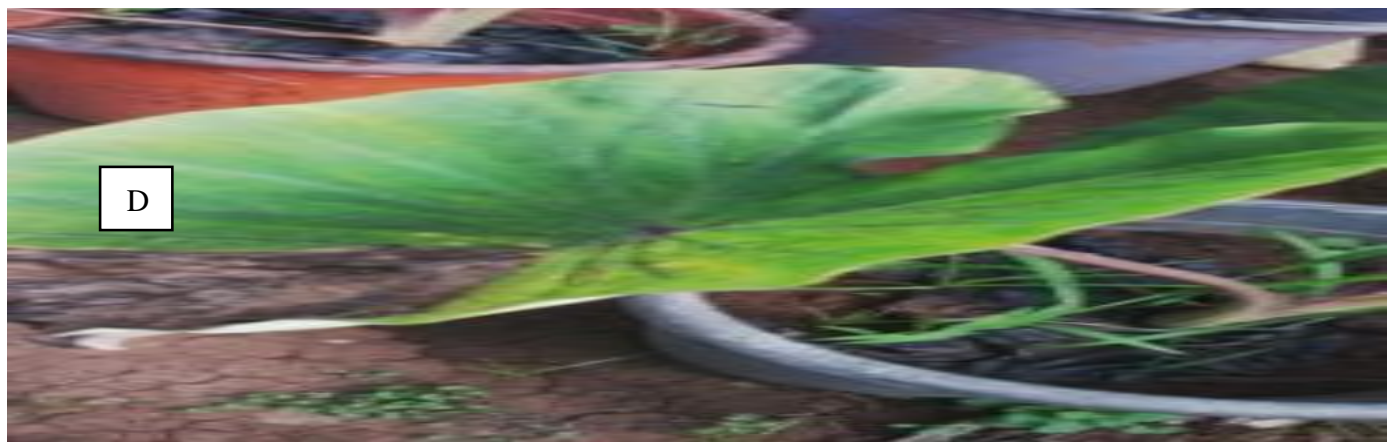

Plate 4:Dark brown halo concentrated at the leaf apex

Jugurnauth, et al. (2001), the following symptoms indicated

Stages of development of symptoms of TLB disease of taro on a susceptible taro

Plates 5 to 8 given below showed stages of development of symptoms of TLB disease on a susceptible taro. 5, was an indication of a healthy leaf, 6 , yellowing covering entire leaf margin, 7 , yellowing covering entire leaf and finally plate 8 shows browning and defoliation of leaf. According to the susceptible varieties; brown to olive green spots on leaf, edge of the spots diffuse, lesions becoming tan/ brown or dark brown/ black edge. Highly susceptible cultivars were expected to produce smaller leaves on shorter petioles. The leaves could be completely destroyed by the blight just as indicated on plate 8 of KNY/BSA/41.

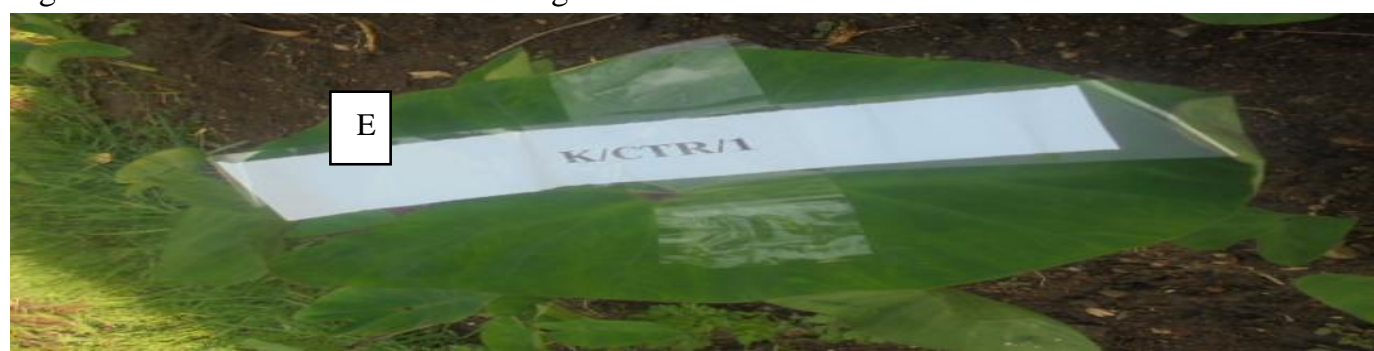

Plate 5: Healthy susceptible leaf

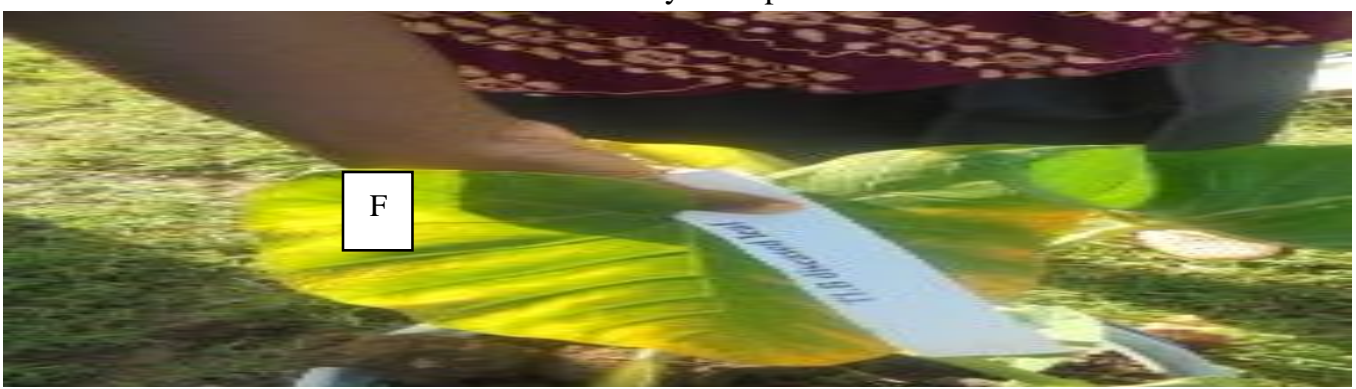


Plate: 6:Yellowing spread throughout leafmargin

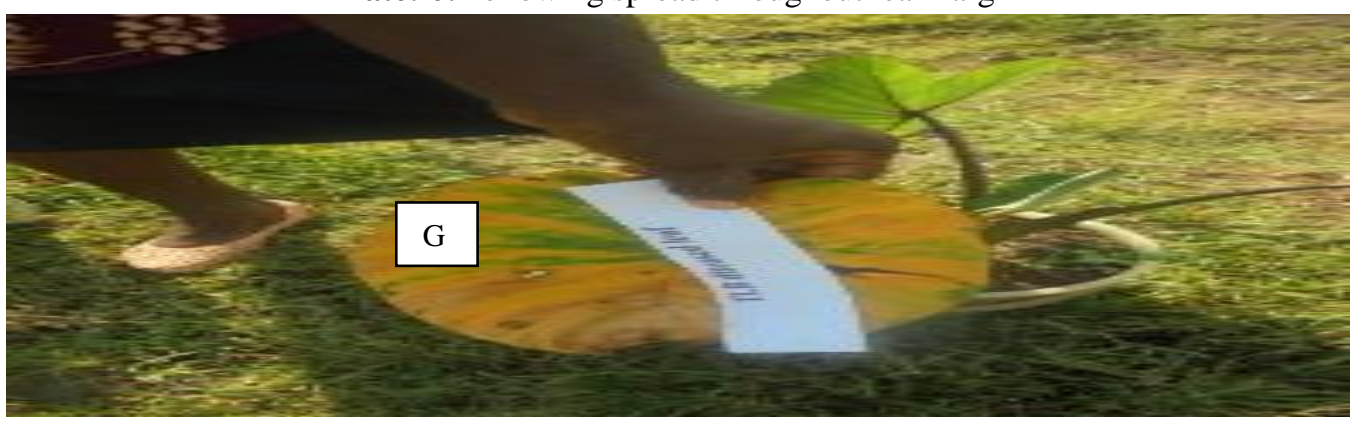

Plate 7:Yellow patches covering the entire leaf

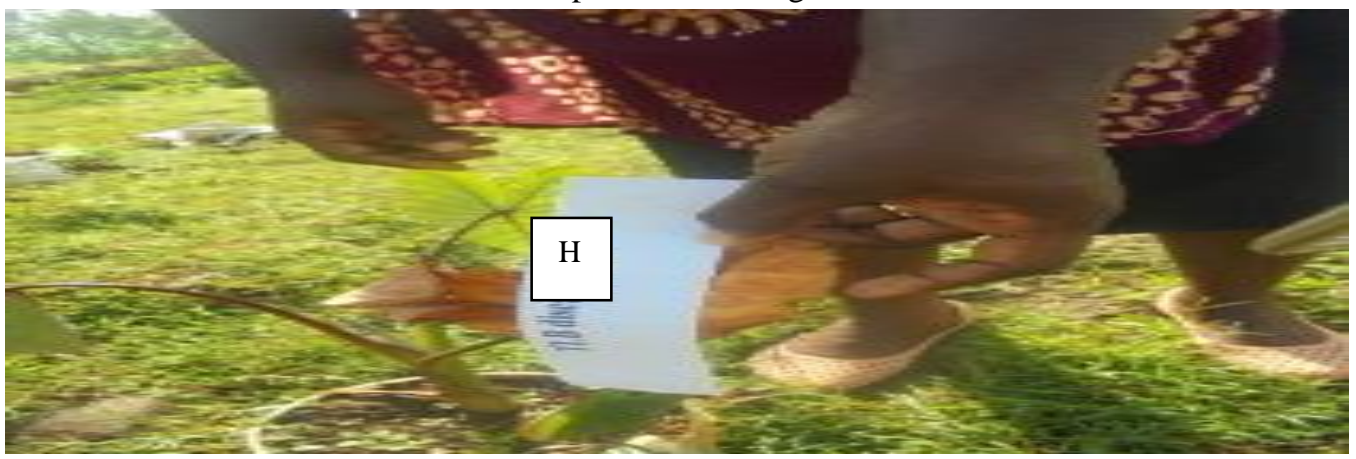

Plate 8: Browning / blackening of and defoliation of leaf

disease development during the period of study. Pataky et al. (1998) reported from his study on disease severity and yield

\section{DISCUSSION}

\section{A. Relationship between TLB resistance and agronomic traits of Pacific-Caribbean and Kenyan taro accessions under field study}

The generally high TLB disease resistance observed in this particular study could have been attributed to the fact that the study area had previously not been used for taro or any related crop hence low disease prevalence. The variation in disease resistance between the Pacific-Caribbean and Kenyan taro could be due to the varied environmental conditions exhibited in regions of plant collection. Atak, (2016) reported in concurrence to this present finding that cultivars from different regions of Spain collected to determine their fungal disease resistance, had generally high sensitivity to the pathogen except for some collected from the humid regions of Spain. These cultivars showed more resistance than those from other regions. Varied reaction to TLB exhibited between Pacific-Caribbean and Kenyan taro accession was similar to the result reported by Padmaja, (2013) on his studies on TLB disease that disease reaction of 37 accessions of taro showed differences in disease resistance. The results also suggested that Pacific-Caribbean accessions did exhibit qualitative and quantitative (rate-reducing) resistance which limit the spread of TLB disease. The results further suggested that the level of resistance within genotypes also affected the disease development over time. The close to similar resistance between Pacific-Caribbean and Kenyan taro disease resistance during early stages of development could be attributed to conditions being less conducive for TLB of sweet corn hybrid that the reactions of the most resistant cultivars could not be differentiated when conditions were less conducive for the development of Northern leaf blight. Further improvement of resistance to TLB in taro would then require evaluation of breeding materials in environments that are least conducive to taro leaf blight. The result that indicated high TLB disease resistance among some Kenyan taro accessions was in accordance with reports of Ackah et al. (2014) that some reasonable resistance to taro leaf blight could be found in local germplasm just has been reported in Kakamega and Eldoret taro accessions of Kenya.

\section{B. Relationship between TLB disease resistance and agronomic traits of Pacific-Caribbean and Kenyan taro accessions under greenhouse study.}

The wide variation of resistance to TLB between the Pacific-Caribbean and Kenyan taro alludes to long term co-evolution of Phytophthora colocasiae and taro within the Kenyan taro. It is thus conceivable that among both host and pathogen, there was a wide array of pathogenicity and resistance genes respectively. Strains of the fungal pathogen could also have producedexcessive anti resistance factors in the susceptible cultivars to breakdown their resistance. This study showed that more Pacific-Caribbean taro accessions could be used as sources of resistance to TLB infection. Tsatsia and Jackson (2015) in a leaflet produced by the Ministry of Agriculture and Livestock, Solomon Islands, with support from IPPSIT reported that breeding programs in Papua New Guinea and Samoa had produced plants resistant to taro leaf blight. In Solomon Islands, a hybrid, LA16, had been found to be resistant to taro leaf blight. Kenyan 
accessions were neither screened nor were known to be resistant to taro leaf blight. The number of leaves of Pacific-Caribbean and Kenyan taro were statistically the same. Those of Pacific-Caribbean taro accessions recorded an average of 4.48 and Kenyan accessions 4.45 leaves. This could have been due to the fact that greenhouse was controlled and therefore very minimal environmental effects were realized. It was important to note that no significant correlation was obtained between TLB disease resistance and agronomic traits.

\section{CONCLUSION AND RECOMMENDATION}

The identification of some Kenyan taro accessions to be moderately resistant to TLB was a plus to our country as the accessions could be considered possible candidates for further breeding purposes although some of them were low yielding. The moderate resistant accessions such as; CE/IND/0, BL/SM/92, BL/SM/80, BL/SM/151, BL/SM/83, $\mathrm{BL} / \mathrm{SM} / 25, \quad \mathrm{BL} / \mathrm{SM} / 120, \quad \mathrm{BL} / \mathrm{SM} / 136, \quad \mathrm{BL} / \mathrm{SM} / 13$, $\mathrm{KNY} / \mathrm{KAK} / 16$ with multiple comparisons with the most resistant cultivars can be used to produce source of resistance to taro leaf blight caused by the fungus Phytophthora colocasiae for better yield. Pacific - Caribbean taro having been screened from their location of origin, yielded higher disease resistance than the Kenyan taro. The highest disease resistance of $89.73 \%$ was obtained from Pacific - Caribbean taro BL/SM/128 and the lowest of $58.27 \%$ from KNY/SYA/51. None of the Pacific - Caribbean taro had below $73.81 \%$ resistance. The disease is therefore a major constraint to taro production in Kakamega county of Kenya. However, sources of resistance to TLB of taro possibly do exist within the Kenyan taro accessions; Kakamega KNY/KAK/16 with $82.9 \%$ and Uashin Gishu KNY/ELD/75 with $84.34 \%$ resistance. However, the identified accessions needed further evaluations under more disease pressure as well as under diverse environments.

The identification of some Kenyan taro accessions to be moderately resistant to TLB was a plus to our country as the accessions could be considered possible candidates for further breeding purposes although some of them were low yielding. The moderate resistant accessions such as; CE/IND/0, BL/SM/92, BL/SM/80, BL/SM/151, BL/SM/83, $\mathrm{BL} / \mathrm{SM} / 25, \quad \mathrm{BL} / \mathrm{SM} / 120, \quad \mathrm{BL} / \mathrm{SM} / 136, \quad \mathrm{BL} / \mathrm{SM} / 13$, $\mathrm{KNY} / \mathrm{KAK} / 16$ with multiple comparisons with the most resistant cultivars can be used to produce source of resistance to taro leaf blight caused by the fungus Phytophthora colocasiae for better yield. Based on the present results, the identified resistant and moderately resistant taro accessions could be suggested for future breeding however, artificial screening of them with most virulent isolates of Phytophthora colocasiae should be conducted to enhance production of resistant taro in Kenya.The resistant and moderately resistant accessions especially under greenhouse conditions such as; BL/HW/26 CE/IND/01, BL/HW/08, BL/SM/25, BL/SM/92, CA/JP/03, CE/THA/07, $\mathrm{KNY} / \mathrm{KAK} / 16$, KNY/MU/75 and KNY/SYA/50 require multiple comparisons with other resistant cultivars from other countries who have produced resistant accession like China in order to produce source of resistance to TLB. Kenyan taro accessions found to be moderately resistant should be evaluated further in taro leaf blight endemic areas to authenticate the durability of their moderate resistance. The knowledge about the genetic diversity of taro in terms of disease resistance and agronomical traits should be pursued in all taro growing regions of Kenya for potential mitigation of leaf blight of taro. Agronomical evaluation conducted will assist in the recommendation of best varieties for farmers.

\section{REFERENCES}

[1] Ackah, F.K., Van der puije, G.C. and Moses, E. (2014).First evaluation of taro (Colocasiae esculenta) genotypes against leaf blight (Phytophthora colocasiae) in Ghana. Hort Flora Research Spectrum 3(4): 390-391

[2] Adipala, E., Lipps, P.E. and Madden, L.V. (1993). Use of disease assessment methods in predicting yield loss due to northern leaf blight of maize. African Crop Science Journal.,1(2): 159-173.

[3] Adomako, J., Kwoseh, C.K., Moses, E and Larbi-Koranteng, S. (2016) Prevalence of Phytophthora Leaf Blight of taro (Colocasiae esculenta (L.) Schott) in the semi deciduous forest zone of Ghana. AJEA,11(4): $1-7$

[4] Atak, A. (2016).Determination of Downy Mildew and Powdery Mildew Resistance of Some Grape Cultivars. South African Journal 38: 13

[5] Ayogu, C.J, Ike, C.U, Ogbonna, O.I, Nnaemeka, GK. (2015) Agricultural Extension Roles towards adapting to the effects of taro leaf blight (TLB) disease in Nsukka Agricultural Zone, Enugu State. Journal of Biology, Agriculture and Health care. 5:12 pp 46.

[6] Bassey, E., Umoh, G., N. U. Ndaeyo1, N. E. Nneke1 and G.U. Akpan, (2016). Investigations into Taro (Colocasiae esculenta (L.) Schott) Leaf Blight Outbreak and Identification of Resistant Cultivars in Akwa Ibom State, Nigeria International Journal of Current Resource in Bioscience and Plant Biology. (5): 137-143

[7] Benjaw, D.T. (2017). Review of taro (Colocasiae esculenta) genetics and breeding.

[8] Journal of Agriculture 5: pp 4

[9] Brooks, F.E., (2000). Methods of measuring taro leaf blight severity and its effect on yield. www.researchgate.net/publication/237523557 accessed 2/9/2013.

[10] Brooks, F.E. (2005). Taro leaf blight. The plant health instructor. American Phyto pathological society.DOI:10.1094/PH1-1-2005-0531-01.http://www.apsnet.org/ed center/introop/lessons/fungi/oomycetes/pages/taro leaf blight.aspx accessed 3/9/2012.

[11] Brooks, F. E. (2008). Detached-leaf bioassay for evaluating taro resistance to Phytophthora colocasiae. Plant Diseases. 92:126-131.

[12] Brooks, F.E. (2011). Methods of measuring taro leaf blight severity and its effects on yield www 2.ctahr.hawaii.edu/adapt/scc-/and Grant/ Dr brooks accessed 3/9/2012.

[13] Cadle-Davidson, L., Chicoine, D.R. and Consolie, N.H. (2011). Variation within and among Vitis spp. for foliar resistance to the powdery mildew pathogen Erysiphe necator. Plant Diseases 95 202-211.

[14] Chan, L.F., Lu, C.T. Lu, H.Y. and Lai, C.H. (1993). A simple method for estimating leaf area in wetland taro (Colocasiae esculenta (L.) Schott). Journal of Agricultural Research, China, 42:162-172.

[15] Chiejina N.V. and Ugwuja F.N. (2013) Incidence of Phytophthora Leaf-Blight Disease of Cocoyam in Nsukka Area of South-Eastern Nigeria. Journal of Botanical Research, ISSN: 0976-9889 \& E-ISSN: 0976-9897, 4(1):21-24.

[16] Dipa. (2017). The effectiveness of various formulation of endophytic bacteria from mangrove to control Phytophthora leaf blight on Japanese taro. Final report pp 4-74.

[17] Do Vale, F.X.R., Parlevliet, J.E and Zambolin, L. (2001).Concepts in plant disease resistance. A review. Fitopatologia Brasileira. Volume 26 pp 3 
[18] Fernando, T.H.P.S., Jayasinghe, C.K., Wijesundera, R.L.C and Siriwardane, D (2012). Some factors affecting in vitro production, germination and viability of conidia of Corynespora cassiicola from Hevea brasiliensis. Journal of the National Science Foundation of Sri Lanka, 40: 241-249.

[19] Fonoti, P. (2005). Breeding for resistance to taro leaf blight (Phytophthora colocasiae) in

[20] Samoa. MSc thesis in crop science. Department of crop science school of

[21] agriculture. The university of south pacific. Pp 1-152

[22] Fonoti, P., Tofinga, M.P and Hunter, D.G. (2008). Screening a cycle 1 breeding population of taro (Colocasiae esculenta (L.) for resistance to taro leaf blight in Samoa. Research journal of Biological sciences 3(8): 888-891.

[23] Hunter, D., Brunt, J. and Delp, C. (2001). Aus AID/SPC. Taro Genetic Resources: Conservation and utilization. A Bibliography of taro leaf blight. Secretariat of the Pacific Community Noumea, pp. 119-136.

[24] Hunter, D., Pouno, K and Semisi, S. (2002). The impact of Taro leaf blight in the Pacific Islands with special reference to Samoa http://www.spent/ta rogen/documents/misc-publications/impact 2 accessed 2/2/2013.

[25] Ivancic, A., Kokoa, P., Simin, A and Gunua, T. (1994). Mendelian studies of resistance to taro leaf blight. In: Proceedings of the Second Taro Symposium, Manokwari, Indonesia, Cenderawasih University: Manokwari, Indonesia, 1996, Pp. 97-100.

[26] Jugurnauth, S., Soomary, S and Hanoomanjee, P. (2001). Production of major Colocasiae esculenta spp in Mauritius: Current status, constraints and opportunities. Journal of Agricultural Research and Extension unit 4: 1-43

[27] Kakamega-data.org.Https://en.climate-data.org. Accessed on 13/11/2017.

[28] Lebot, V., Herain, C., Gunua, T., Pardales, J., Prana, M., Thongjiem, M and Viet, N., (2008). Isozyme and RAPD variation among Phytophthora colocasiae isolates from south East Asia and the pacific. Plant Pathology Journal 52, 303-313.

[29] Mabhaudhi, T. (2012).Drought tolerance and water use of selected South African

[30] landraces of taro (Colocasiae esculenta L. Schott) and Bambara ground nut

[31] (Vigna subterranean L. Verdc). A thesis submitted in partial fulfillment of the requirement for the degree of Doctor of Philosophy (Crop science) school of Agriculture, Engineering and Science, University of KwaZulu-Natal Pietermaritzburg, South Africa pp14-241.

[32] Manza, W.S., Zarafi, A.B and Alabi, O. (2008). Incidence of leaf blight caused by Fusarium pallidoroseum on varied age of caster (Ricinus communis) inoculated using different methods. African Journal of General Agriculture 4(2): 1-5

[33] Masinde Muliro maps and directions. www.ac.ke/index.phd/favorites accessed 5/11/2013.

[34] Mbanaso, E. O., Nwakor, F. N., Mbanaso, E. N. A., Asumugha, G. N., Abachi, U., (2008). Guide to Cocoyam Minisett Production, Extension Guide No. 22, Extension Services Programme, N. R. C. R, Umudike, Nigeria. pp. 1 - 10

[35] Mbong, G.A., Fokunang, C.N., Lum, A and Fontem, E.A. (2013). An overview of phytophthora colocasiae of cocoyam: A potential economic disease of food security in Cameroon: Journal of Agriculture and Food Science www resource journals org/jacs 1 (9): 140-145.

[36] Mishra, A.K, Sharma, K and Misra, R.S. (2010) Cloning and characterization of cDNA encoding an elicitor of Phytophthora colocasiae. Microbiological Resource 165:9

[37] Mukherjee, D., Roquib, A., Das, N.D., Mukherjee, S. (2016). A Study on Genetic Variability, Character Association and Path Co-Efficient Analysis on Morphological and Yield Attributing Characters of Taro (Colocasia esculenta (L.) Schott). American Journal of Plant Sciences, 7: 479-488

[38] Nath, V.S., Basheer, S., Jeeva, M.L and Veena, S.S. (2016).Genetic and phenotypic characterization of Phytophthora colocasiae in taro growing areas of India. Journal of plant pathology and microbial 7:383.

[39] Nath, V. S., Hedge, V.M, Muthulekshmi, L.J., Misra, R.S., Veena, S.S., Jaj, M., Suresh, K., Unnikrashnan, L and Darveekaran, S.S. (2014). Rapid and sensitive detection of Phytophthora colocasiae responsible for the taro leaf blight using conventional and real-time PCR assaypp 354 